University of Nebraska - Lincoln

DigitalCommons@University of Nebraska - Lincoln

Biological Systems Engineering: Papers and

Publications

Biological Systems Engineering

2012

\title{
Trapping Phosphorus in Runoff with a Phosphorus Removal Structure
}

\author{
Chad J. Penn \\ Oklahoma State University - Main Campus, chad.penn@okstate.edu \\ Joshua M. McGrath \\ Oklahoma State University - Main Campus \\ Elliott Rounds \\ Oklahoma State University - Main Campus \\ Garey A. Fox \\ Oklahoma State University - Main Campus, gafox2@ncsu.edu \\ Derek M. Heeren \\ University of Nebraska-Lincoln, derek.heeren@unl.edu
}

Follow this and additional works at: https://digitalcommons.unl.edu/biosysengfacpub

Part of the Bioresource and Agricultural Engineering Commons, Environmental Engineering Commons, and the Other Civil and Environmental Engineering Commons

Penn, Chad J.; McGrath, Joshua M.; Rounds, Elliott; Fox, Garey A.; and Heeren, Derek M., "Trapping Phosphorus in Runoff with a Phosphorus Removal Structure" (2012). Biological Systems Engineering: Papers and Publications. 301.

https://digitalcommons.unl.edu/biosysengfacpub/301

This Article is brought to you for free and open access by the Biological Systems Engineering at DigitalCommons@University of Nebraska - Lincoln. It has been accepted for inclusion in Biological Systems Engineering: Papers and Publications by an authorized administrator of DigitalCommons@University of Nebraska Lincoln. 


\title{
Trapping Phosphorus in Runoff with a Phosphorus Removal Structure
}

\author{
Chad J. Penn,* Joshua M. McGrath, Elliott Rounds, Garey Fox, and Derek Heeren
}

Reduction of phosphorus (P) inputs to surface waters may decrease eutrophication. Some researchers have proposed filtering dissolved $\mathrm{P}$ in runoff with $\mathrm{P}$-sorptive byproducts in structures placed in hydrologically active areas with high soil $\mathrm{P}$ concentrations. The objectives of this study were to construct and monitor a $\mathrm{P}$ removal structure in a suburban watershed and test the ability of empirically developed flow-through equations to predict structure performance. Steel slag was used as the P sorption material in the $\mathrm{P}$ removal structure. Water samples were collected before and after the structure using automatic samples and analyzed for total dissolved P. During the first 5 mo of structure operation, 25\% of all dissolved $\mathrm{P}$ was removed from rainfall and irrigation events. Phosphorus was removed more efficiently during low flow rate irrigation events with a high retention time than during high flow rate rainfall events with a low retention time. The six largest flow events occurred during storm flow and accounted for $75 \%$ of the $\mathrm{P}$ entering the structure and $54 \%$ of the P removed by the structure. Flow-through equations developed for predicting structure performance produced reasonable estimates of structure "lifetime" (16.8 mo). However, the equations overpredicted cumulative P removal. This was likely due to differences in $\mathrm{pH}$, total $\mathrm{Ca}$ and $\mathrm{Fe}$, and alkalinity between the slag used in the structure and the slag used for model development. This suggests the need for an overall model that can predict structure performance based on individual material properties.
Copyright $\odot 2012$ by the American Society of Agronomy, Crop Science Society of America, and Soil Science Society of America. All rights reserved. No part of this periodical may be reproduced or transmitted in any form or by any means, electronic or mechanical, including photocopying, recording, or any information storage and retrieval system, without permission in writing from the publisher.

J. Environ. Qual. 41:672-679 (2012)

doi:10.2134/jeq2011.0045

Posted online 1 Nov. 2011

Received 14 Feb. 2011.

*Corresponding author (chad.penn@okstate.edu).

(c) ASA, CSSA, SSSA

5585 Guilford Rd., Madison, WI 53711 USA
$\mathrm{R}$ EDUCTION OF PHOSPHORUS (P) loading to surface waters can help to prevent eutrophication. Previous studies have suggested the use of certain industrial byproducts as $\mathrm{P}$ sorption materials (PSMs) for reducing $\mathrm{P}$ solubility in high-P soils (Leader et al., 2008; Makris and Harris, 2006; Rhoton and Bigham, 2005). Although the addition of PSMs to high-P soils has been shown to reduce water-soluble $\mathrm{P}$ and therefore losses of dissolved $\mathrm{P}$ in runoff (Gallimore et al., 1999), such reductions in $P$ solubility can be temporary (Penn and Bryant, 2006). In addition, such an approach does not truly remove $\mathrm{P}$ from the watershed; P pools within the soil solid phase are simply shifted to less soluble forms.

A potential modification to this approach is a $\mathrm{P}$ removal structure. Such structures can be filled with PSMs and can be strategically placed in "hot spots" or drainage ditches where runoff with elevated concentrations of dissolved P regularly occurs (Penn et al., 2010). The P removal structure is designed to intercept runoff or subsurface drainage and channels flow through contained PSMs. After the PSMs become saturated with P, they can be replaced with new PSMs; using this approach, P can be effectively removed from the watershed. Some potential guidelines, theory, and approach for P removal structure design are presented in Penn et al. (2010). Similarly, previous studies have used various PSMs for removing P from wastewaters (Koiv et al., 2010; Cucarella and Renman, 2009; Wei et al., 2008) and subsurface drainage (McDowell et al., 2008). A material that has shown tremendous promise as a PSM in column studies is steel slag (Drizo et al., 2008, 2006, 2002), which is a by-product of the steel industry.

In a previous study, Penn and McGrath (2011) constructed a pilot scale pond filter that used electric arc furnace steel slag as the PSM. The authors developed empirical equations based on laboratory flow-through experiments that predicted structure performance as a function of retention time (RT) (i.e., the time required for one pore volume to pass through the structure) and inflow P concentration. At a RT of $10 \mathrm{~min}$, the pond filter removed $34 \%$ of the all $\mathrm{P}$ pumped into it $(172 \mathrm{mg}$ $\mathrm{kg}^{-1}$ of PSM) at the point of $\mathrm{P}$ saturation (i.e., the point at which $\mathrm{P}$ was no longer removed from passing water). The flowthrough equations reasonably predicted structure performance (P removal and longevity), whereas the Langmuir equation

Dep. of Plant and Soil Science, Oklahoma State Univ., 367 Agricultural Hall, Stillwater, OK, 47078-1020. Assigned to Associate Editor Gerwin F. Koopmans.

Abbreviations: DI, deionized; ICP-AES, inductively coupled plasma atomic emission spectroscopy; PSM, phosphorus-sorbing material; PVC, polyvinyl chloride; RhWT, rhodamine; RT, retention time. 
developed from a batch isotherm experiment with the same PSM material failed.

Other studies have shown potential for the development of P removal structures. Penn et al. (2007) constructed a P removal structure in a drainage ditch located on the Eastern Shore of Maryland. This structure was filled with $226 \mathrm{~kg}$ of acid mine drainage residual, and the PSM was able to remove 99\% of the $\mathrm{P}, \mathrm{Zn}$, and $\mathrm{Cu}$ that flowed into it during a 24-h rainfall event that produced $30 \mathrm{~cm}$ of precipitation. However, the structure soon thereafter failed as a result of flow becoming restricted through it (i.e., clogging). Agrawal et al. (2011) tested a cartridge filtration system on a golf course green subsurface drainage system for removing $\mathrm{P}$ and several pesticides using a mixture of slag, zeolite, cement kiln dust, silica sand, and coconut shell-activated carbon. Although the system was effective for removing certain pesticides, it was ineffective at removing P, likely due to the small amount of slag used in the filtration system $(3.5 \mathrm{~L})$.

There are no published studies on monitoring of a $\mathrm{P}$ removal structure. Therefore, the objectives of this study were to construct and monitor a $\mathrm{P}$ removal structure in a suburban watershed and to test the ability of previously constructed flow-through equations for predicting structure performance.

\section{Materials and Methods Site Description}

The P removal structure was placed at the outlet of a 320-ha suburban watershed in Stillwater, Oklahoma. The watershed land use consisted of approximately 35,50 , and $15 \%$ residental, undeveloped, and gof course, respectively. Two irrigated golf greens were located within 130 to $150 \mathrm{~m}$ from the structure. The greens were regularly irrigated by golf course personnel as necessary, and this irrigation produced runoff that reached the P removal structure. The structure was located in a drainage ditch immediately on the downstream side of a drainage culvert (Fig. 1) where all water exited the watershed via a concrete trapezoidal bar ditch maintained by the city of Stillwater. The bar ditch drained directly into Stillwater

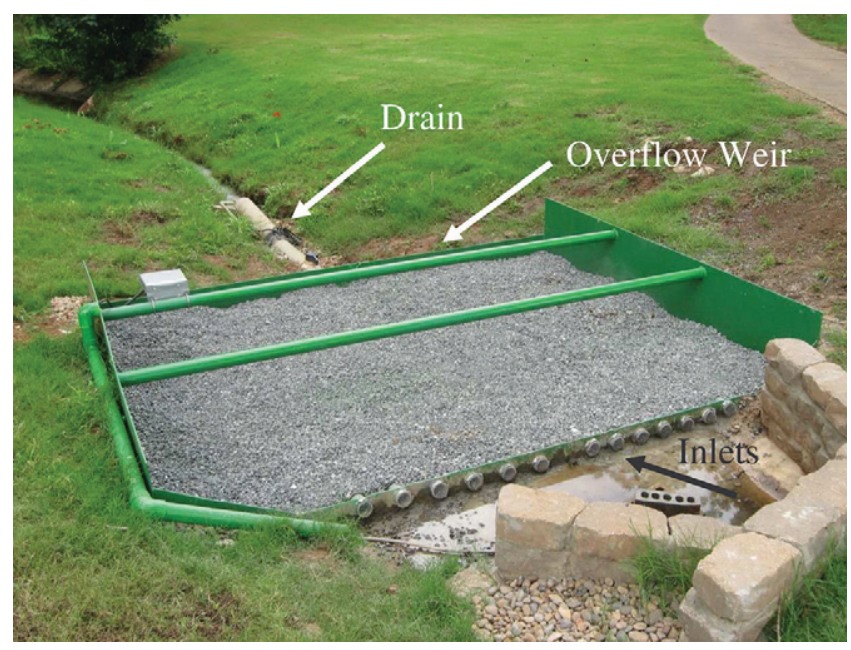

Fig. 1. Picture of the phosphorus $(P)$ removal structure with runoff inlets, drain for treated water, and overflow weir. The P sorption material in the structure is $2712 \mathrm{~kg}$ of 6.3 - to $11-\mathrm{mm}$-diameter steel slag.
Creek. Some runoff entered the structure by flowing along the side of the culvert into the structure inlet (Fig. 1).

\section{Structure Construction and Runoff Sampling}

The $\mathrm{P}$ removal structure was $2.4 \mathrm{~m}$ wide $\times 3 \mathrm{~m}$ long $\times 0.2 \mathrm{~m}$ deep and was constructed using 0.63 -cm-thick carbon steel with all joints welded to be water tight. The structure was welded in situ along with two 3 -m steel support pipes ( $5 \mathrm{~cm}$ diameter). The bottom of the structure was set to a 3\% slope toward the outlet. Thirteen inlet pipes $(5 \mathrm{~cm}$ diameter $)$ were welded into the front plate of the structure, and then each pipe was adapted to polyvinyl chloride (PVC) pipe of the same diameter inside the structure. Each PVC pipe was $2.3 \mathrm{~m}$ long and perforated (four rows of $0.635-\mathrm{mm}$ diameter holes at $5 \mathrm{~cm}$ apart) to evenly distribute inflow water throughout the surface of the structure. The perforated distribution manifold is not visible in Fig. 1 because the pipes are buried immediately below the surface. A $10-\mathrm{cm}-$ diameter steel drainage pipe was welded at the bottom center of the downstream side of the structure; this pipe was adapted to a 15.2-cm-diameter PVC pipe fitted with a shutoff valve. All steel was treated with two coats of primer and paint.

Two Isco 6712 (Teledyne Isco Inc., Lincoln, NE) automatic samplers were housed on site in a small plastic building to take runoff samples at the structure inlet and outlet (drainage pipe) during flow events. In addition, the automatic sampler for the outflow side of the structure was fitted with an Isco 730 flow module ("bubbler"), which was connected to a 15.2-cm-flow orifice insert placed in the structure drainage pipe (outflow). The 730 flow module was programmed to take a flow rate measurement every minute. The automatic sampler for the outflow water was programmed as the "primary" and began sampling when flow was detected; the inlet sampler was programmed as the "slave" to the outflow sampler and therefore was triggered to sample at the same time as the outflow sampler. Discrete (not composited) samples $(800 \mathrm{~mL}$ ) were taken using two programs; from 0 to $34.5 \mathrm{~L} \mathrm{~min}^{-1}$ samples were taken every $30 \mathrm{~min}$, and at flow rates $>34.5 \mathrm{~L} \mathrm{~min}^{-1}$ samples were taken every $45 \mathrm{~min}$. Regarding potential "overflow" runoff events, an Isco 2112 ultrasonic probe was fitted near the downstream side of the structure to monitor the depth of water on top of the structure. The Isco 2112 could provide the flow rate of untreated overflow water during events that exceeded the capacity of the structure. Therefore, outlet flow volume plus overflow volume equals total ditch flow volume.

Electric arc furnace steel slag was obtained from a steel mill in Ft. Smith, Arkansas (Tube City IMS). Slag was sieved at a nearby gravel quarry to achieve a size of 6.35 to $11 \mathrm{~mm}$ in diameter. Previous experiments showed that the nonsieved slag had a limited saturated hydraulic conductivity (Penn et al., 2011). Approximately $2712 \mathrm{~kg}$ of the sieved slag was placed in the P removal structure on 10 July 2010.

\section{Dye Test}

A rhodamine WT (RhWT) dye test was conducted to quantify hydraulic RT in the structure. A constant water flow rate was discharged into a pool of water at the inlet of the structure (Fig. 1) for approximately $1 \mathrm{~h}$ to achieve steady state flow before initiating the dye test. The dye was injected into the inflow solution and monitored in the inflow and outflow 
over time. The dye test was simulated using CXTFIT (version 2.1) (Toride et al., 1999), a model used extensively for solving the one-dimensional convective-dispersion equation for solute transport through soils (e.g., Baumann et al., 2002; Lee et al., 2002). Fate and transport parameters in the model, such as pore velocity, hydrodynamic dispersion, and retardation coefficient, were optimized to the observed RhWT concentrations. This process is also known as "inverse estimation" of model parameters, as opposed to forward modeling, where parameters are input and concentrations are predicted. From these fate and transport parameters, various characteristics of the flow and contaminant transport system can be measured, such as the RT and Peclet number. Physical and chemical equilibrium of RhWT was assumed. The input boundary condition for the dye was modeled in CXTFIT as multiple pulse inputs based on measured inflow concentrations. CXTFIT used a nonlinear least-squares parameter optimization method to derive the dye transport parameters (i.e., velocity and dispersion coefficient) that best predicted the outflow RhWT concentrations. The inversely estimated velocity from CXTFIT was used to estimate the average RT of the dye in the structure.

\section{Analysis of Water Samples and Slag}

All water samples were collected within $12 \mathrm{~h}$ of a runoff event, filtered through a $0.45-\mu \mathrm{m}$ membrane, and refrigerated. Samples were analyzed within $3 \mathrm{~d}$ for P, copper $(\mathrm{Cu})$, zinc $(\mathrm{Zn})$, chromium $(\mathrm{Cr})$, and boron (B) by inductively coupled plasma-atomic emission spectroscopy (ICP-AES). A pH probe was used to measure $\mathrm{pH}$ in all samples. Alkalinity was determined by automatic titration (TitriLab 865; Radiometer Analytical, Villeurbanne Cedex, France) to $\mathrm{pH}$ 4.5.

All analyses of steel slag used in the P removal structure were conducted in triplicate. Slag $\mathrm{pH}$ was determined with a $\mathrm{pH}$ meter using a solid/deionized (DI) water ratio of 1:5 (w/v). Alkalinity was determined as previously described using $2 \mathrm{~g}$ of material suspended in $20 \mathrm{~mL}$ of DI water. Slag was ground before analysis of total elements by the EPA 3051 nitric acid digestion method (USEPA, 1997). Digestion solutions were analyzed for $\mathrm{Ca}, \mathrm{Mg}, \mathrm{S}, \mathrm{Fe}$, and $\mathrm{Al}$ by ICP-AES. Samples were also extracted with DI water at a 1:10 (w/v) solid/solution ratio for $1 \mathrm{~h}$, followed by filtration with a $0.45-\mu \mathrm{m}$ filter and analysis for $\mathrm{Ca}, \mathrm{Mg}, \mathrm{S}, \mathrm{Fe}$, and $\mathrm{Al}$ by ICP-AES.

A standard batch isotherm was conducted for the slag using $2 \mathrm{~g}$ of sample and $16 \mathrm{~h}$ equilibration (shaking) in $30-\mathrm{mL}$ solutions of $0,1,10,25,50$, and $100 \mathrm{mg} \mathrm{P} \mathrm{L} \mathrm{P}^{-1}$. Phosphorus solutions were made using $\mathrm{KH}_{2} \mathrm{PO}_{4}$, and the matrix solution consisted of 5.6, 132, 110, 10, and $17 \mathrm{mg} \mathrm{L}^{-1}$ of $\mathrm{Mg}, \mathrm{Ca}, \mathrm{S}$, $\mathrm{Na}$, and $\mathrm{K}$, respectively, adjusted to a $\mathrm{pH}$ of 7 . Reagent-grade magnesium sulfate, calcium sulfate, sodium chloride, and potassium chloride were used to make the matrix. This matrix was chosen because it was found to be representative of agricultural runoff measured in a previous study (Penn et al., 2007). After equilibration, solutions were centrifuged for $15 \mathrm{~min}$ and filtered through a $0.45-\mu \mathrm{m}$ filter before $\mathrm{P}$ analysis by ICP-AES.

Phosphorus sorption was quantified by the difference between $P$ concentrations added and the final equilibrated concentrations. These values were applied to a nonlinear Langmuir using the following equation:
$S=\frac{S_{\max } K C}{1+K C}$

where $S$ is the sorbed $\mathrm{P}$ concentration $\left(\mathrm{mg} \mathrm{kg}^{-1}\right), S_{\text {max }}$ is the maximum sorption capacity of the soil $\left(\mathrm{mg} \mathrm{kg}^{-1}\right), K$ is the Langmuir binding strength coefficient $\left(\mathrm{L} \mathrm{mg}^{-1}\right)$, and $C$ is the equilibrium concentration $\left(\mathrm{mg} \mathrm{L}^{-1}\right)$. The best fit model parameters for the nonlinear equation were obtained by finding the combinations of parameters that provided the best fit to the observed data. This was done by using an Excel spreadsheet as prepared and described by Bolster and Hornberger (2007). This program was designed to provide $K$ and $S_{\max }$ values in addition to the "goodness-of-fit" indicator, model efficiency (E). An $\mathrm{E}$ value of 1 indicates a perfect fit of the data, and $\mathrm{E}<$ 0 indicates that taking the average of all measured $\mathrm{P}$ sorption values in the isotherm would give a better prediction than the model (Bolster and Hornberger, 2007).

\section{Calculations}

Flow and sampling data were synchronized with Flow Link software (Teledyne Isco Inc., Lincoln, NE) when downloaded directly from the automatic samplers. Because flow rate measurements were taken every minute, the discrete runoff volume produced at any given minute can be determined by:

Discrete runoff volume $=$ flow rate $* 1$

where discrete runoff volume is expressed in liters and flow rate in $\mathrm{L} \mathrm{min}{ }^{-1}$. Discrete runoff volume was calculated at every minute for each flow event. Therefore, the total runoff volume produced for a given time period could be determined by the sum of all discrete runoff volumes over that time period. Weighted average flow rate $\left(\mathrm{L} \mathrm{min}^{-1}\right)$ was calculated as:

Weighted average flow rate $=\frac{\text { total runoff volume }}{\text { total runoff time }}$

where total runoff volume and time are in units of liters and minutes, respectively. Phosphorus loading to the structure between each sampling point was calculated by integrating $\mathrm{P}$ concentrations with respect to flow volume. The sum of all $\mathrm{P}$ loads for each sampling point interval represents the total $\mathrm{P}$ load for an event. This value is used to calculate flow-weighted $\mathrm{P}$ concentrations $\left(\mathrm{mg} \mathrm{L}^{-1}\right)$ :

Flow-weighted P concentration $=\frac{\mathrm{P} \text { load }}{\text { total flow volume }}$

where P load and total volume are in units of milligrams and liters, respectively. After P loads were determined for inflow and outflow (treated) water, the P removal (mg) could be calculated as a mass balance:

$\mathrm{P}$ removed $=$ inlet $\mathrm{P}$ load - outflow $\mathrm{P}$ load

where inlet and outflow P load are expressed as milligrams. Retention time (in minutes) of the structure at different flow rates was also estimated as described in Penn and McGrath (2011):

Retention time $=\frac{\text { total structure pore space }}{\text { flow rate at outlet }}$ 
where total structure pore space and flow rate at outlet are in units of liters and $\mathrm{L} \mathrm{min}^{-1}$, respectively. Total pore space $(574 \mathrm{~L}$ ) was calculated based the total mass of material $(2712 \mathrm{~kg})$, bulk density $\left(1.8 \mathrm{~g} \mathrm{~cm}^{3}\right)$, and porosity (38\%).

\section{Prediction of Field Results Using an Empirical Model}

A series of empirical flow-through equations developed by Penn and McGrath (2011) was used to compare field results of the $P$ removal structure with the predicted amount of $P$ removed. Although details of the general use of these empirical equations appear in a companion paper (Stoner et al., 2012), we provide a brief description here. The following equations were originally developed by Penn and McGrath (2011) to predict the amount of discrete P removal (\% P removal) with P loading to sieved slag ( $x$ in $\mathrm{mg} \mathrm{P} \mathrm{kg}^{-1}$ ) using an exponential equation:

Discrete P removal $(\%)=b \mathrm{e}^{\mathrm{mx}}$

where $b$ is the $\mathrm{Y}$ intercept and $\mathrm{m}$ is the slope coefficient for this relationship. Because this is an exponential decay equation, $\mathrm{m}$ is always negative. The following equations (significant at $P<$ $0.01 ; R^{2}=0.68$ and 0.48 for Eq. [8] and [9], respectively) are used to estimate the $b$ and $m$ parameters for Eq. [7] as a function of RT and inflow P concentration (Penn and McGrath, 2011):

$\log -\mathrm{m}=(0.08506 \mathrm{RT})-\left(0.07416 C_{\mathrm{in}}\right)-2.53493$

$\log \mathrm{b}=(0.06541 \mathrm{RT})-\left(0.00864 C_{\mathrm{in}}\right)+1.60631$

where $C_{\text {in }}$ is the inflow $\mathrm{P}$ concentration $\left(\mathrm{mg} \mathrm{L}^{-1}\right)$. As described in greater detail in Stoner et al. (2012) and Penn and McGrath (2011), these equations were developed from a series of laboratory flow-through cell experiments in which a known mass of slag was exposed to a flowing $\mathrm{P}$ solution at five different RTs and five different inflow $\mathrm{P}$ concentrations. When parameters $m$ and $b$ are inserted into Eq. [7], the result is a predicted P removal curve specific to the inflow $\mathrm{P}$ concentration and $\mathrm{RT}$ conditions that were input into Eq. [8] and [9]. Integration of the predicted P removal curve (Eq. [7]) yields a prediction of cumulative $\mathrm{P}$ removal (\%) at any given level of $\mathrm{P}$ added $(x$; $\left.\mathrm{mg} \mathrm{kg}^{-1}\right)$ :

Cumulative P removed $=\frac{\int_{0}^{x}\left(b e^{\mathrm{mx}}\right) \mathrm{d} x}{x}$

Phosphorus removal approaches zero (1\%) as described by the equation for the predicted $\mathrm{P}$ removal curve (Eq. [7]) when the $\mathrm{P}$ inflow concentration $\approx \mathrm{P}$ outflow concentration (i.e., the point at which the PSM is "spent"). Insertion of $1 \%$ for cumulative P removed into Eq. [10] and subsequent rearrangement to solve for $x$ results in an estimate of the maximum amount of $\mathrm{P}$ that can be delivered to the P removal structure before the PSM is spent. Such a rearrangement results in the following equation:

Maximum P added $=\frac{\ln b}{-m}$

Insertion of the maximum amount of $\mathrm{P}$ that can be added to the P removal structure as determined from Eq. [11] into Eq. [7] results in the total amount of $\mathrm{P}$ predicted to be removed by the PSM under the conditions (i.e., RT and inflow P concentration) used for the flow-through equations (Eq. [8] and [9]) used to produce the predicted P removal curve.

\section{Results and Discussion Phosphorus Removal Structure: Flow}

Results from the dye test indicated that when a flow rate of $57.1 \mathrm{~L} \mathrm{~min}^{-1}$ was applied to the structure, the average RT was $9.3 \mathrm{~min}$ as estimated by CXTFIT $\left(R^{2}=0.97\right.$ between measured and predicted dye outflow concentrations). This RT is similar to the calculated value of 10 min estimated by Eq. [6].

During the 5-mo period in which all runoff was monitored, there were 54 total runoff events. Twenty of the events were rainfall, and 34 were due to irrigation of nearby golf course greens (Table 1). Over that time period, the rainfall totaled $24.6 \mathrm{~cm}$; the largest rainfall event was $4 \mathrm{~cm}$ on 8 Sept. 2010. The P removal structure was able to treat all water delivered to it, as evidenced by the fact that no water crested the overflow weir, which was continuously monitored with an ultrasonic probe. During the largest rainfall event, the maximum flow rate through the structure was $506 \mathrm{~L} \mathrm{~min}^{-1}$.

As expected, rainfall events produced higher flow rates through the structure than irrigation events from nearby golf greens, which translated into a lower average RT for the rainfall runoff events (Table 1). All runoff samples were analyzed for total dissolved $\mathrm{P}$, and several random irrigation and storm runoff samples were analyzed for dissolved reactive P (i.e., orthophosphate). Because the entire area immediately draining into the structure was well covered with grass, there was no sediment in the samples, and thus $>90 \%$ of the total dissolved P was orthophosphate. The overall flow-weighted average total dissolved $\mathrm{P}$ concentration in runoff delivered to the P removal structure $\left(0.50 \mathrm{mg} \mathrm{L}^{-1}\right)$ is comparable to other studies, including those conducted on agricultural land. Harmel et al. (2004) showed that several agricultural subwatersheds consisting of cultivated crops or pasture that received 0 to $358 \mathrm{~kg} \mathrm{P} \mathrm{ha}^{-1} \mathrm{yr}^{-1}$

Table 1. Summary of the suburban phosphorus removal structure performance over the first 5 mo of operation.

\begin{tabular}{lccc}
\hline & Rainfall runoff events & Irrigation runoff events & All runoff events \\
\hline Number of runoff events & 20 & 34 & 54 \\
Maximum flow rate, $\mathrm{L}$ min $^{-1}$ & 506 & 47 & 506 \\
Weighted average flow rate, $\mathrm{L} \mathrm{min}^{-1}$ & 30.3 & 11.5 & 29.8 \\
Weighted average retention time, min & 18.9 & 50 & 19.3 \\
Maximum runoff P concentration, $\mathrm{mg} \mathrm{L}^{-1}$ & 1.61 & 0.97 & 1.61 \\
Flow-weighted runoff P concentration, $\mathrm{mg} \mathrm{L}^{-1}$ & 0.59 & 0.44 & 0.50 \\
Total P input to structure, $\mathrm{mg} \mathrm{kg}^{-1}$ & 92.1 & 10.7 & 102.8 \\
Total P removed by structure, $\mathrm{mg} \mathrm{kg}^{-1}$ & 19.3 & 6.6 & 25.9 \\
\hline
\end{tabular}


produced average dissolved $\mathrm{P}$ concentrations of 0.09 to $2.29 \mathrm{mg} \mathrm{L}^{-1}$. Among 35 agricultural catchments monitored over $4 \mathrm{yr}$ in Ireland, runoff-dissolved $P$ concentrations ranged from 0.01 to $0.70 \mathrm{mg} \mathrm{L}^{-1}$ (Daly et al., 2002). A golf course in Texas produced an average dissolved $\mathrm{P}$ concentration of $0.13 \mathrm{mg} \mathrm{L}^{-1}$ over 5 yr (King et al., 2007).

Figure 2 shows hydrographs and corresponding inflow total dissolved $\mathrm{P}$ concentrations for typical runoff events from rainfall and irrigation. Not only did rainfall runoff events produce higher dissolved $\mathrm{P}$ concentrations than irrigation runoff events (Table 1 ), but rainfall runoff events also tended to produce increasing $\mathrm{P}$ concentrations with flow rate into the $\mathrm{P}$ removal structure. This suggests that hydrological connectivity increased among certain portions of the watershed as soils became saturated with moisture and runoff increased, allowing runoff from these "variable source" areas (Sharpley et al., 2008) in the watershed to reach the outlet, which is the ditch $\mathrm{P}$ removal structure. Similarly, Pionke et al. (1999) found that dissolved $\mathrm{P}$ concentrations delivered from an agricultural watershed increased with flow rate. In our case, we speculate that high-P soils contribute P to the structure only during large events when they become "connected" and such runoff is able to reach the outlet. Because the irrigation events that occurred throughout the monitoring period were from the same location, runoff produced from such events typically displayed relatively steady runoff $\mathrm{P}$ concentrations delivered to the structure between 0.3 and $0.5 \mathrm{mg} \mathrm{L}^{-1}$ (Fig. 2).

\section{Phosphorus Removal Structure: Phosphorus Removal}

The sum of total dissolved $\mathrm{P}$ delivered to the structure over the 5 -mo period was $0.282 \mathrm{~kg}$ or $0.0047 \mathrm{~kg} \mathrm{ha}^{-1} ; 88 \%$ of this $P$ delivery occurred during rainfall induced runoff events (Table 1). Among all dissolved $\mathrm{P}$ transported in runoff to the P removal structure, $75 \%$ of this was delivered during the six largest rainfall events. Various authors have suggested that large rainfall events export the majority of $\mathrm{P}$ from watersheds (Sharpley et al., 2008; Udawatta et al., 2004; Pionke et al., 1999; Pionke et al., 1997). For example, Pionke et al. (1997) found that $70 \%$ of annual dissolved P loads were exported by the seven largest storms.

During the 5 mo of monitoring, the P removal structure sorbed $25.9 \mathrm{mg} \mathrm{P} \mathrm{kg}^{-1}$ slag, which was $25.2 \%$ of the total dissolved P delivered to it (Table 1). Of the $25.9 \mathrm{mg} \mathrm{P} \mathrm{kg}^{-1}$ sorbed, approximately 75 and $25 \%$ occurred during rainfall and irrigation runoff events, respectively. Phosphorus transported during irrigation runoff events was more efficiently removed by the structure compared with rainfall runoff events (i.e., 62 versus $21 \% \mathrm{P}$ removal for irrigation and rainfall events, respectively) (Table 1). The difference in $P$ removal efficiency among rainfall and irrigation events is likely due to the fact that rainfall runoff events resulted in higher $\mathrm{P}$ concentrations and flow rates. Higher structure flow rates during rainfall runoff events
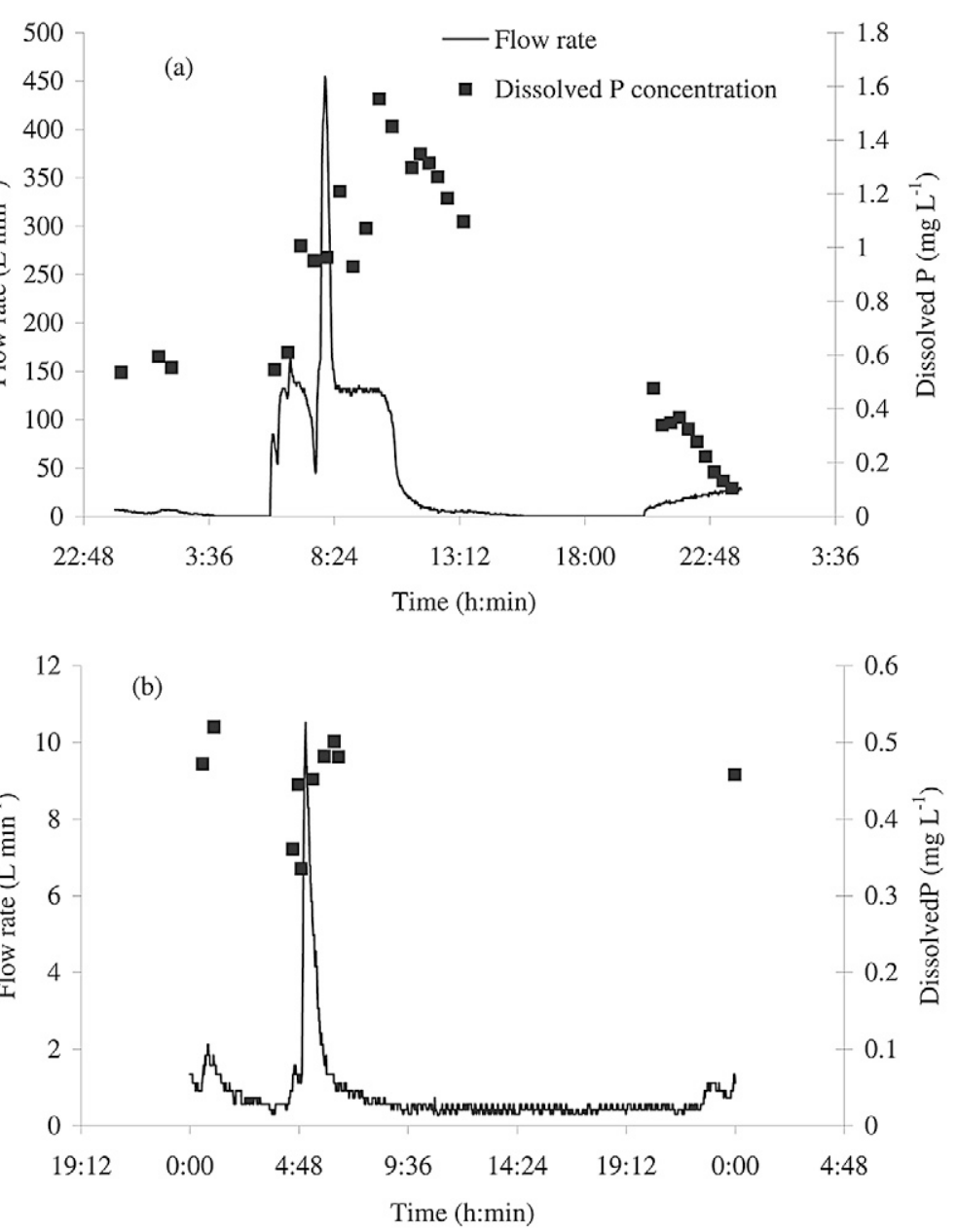

g. 2. Typical hydrograph and corresponding inflow total dissolved phosphorus (P) concentrations to the ditch $P$ removal structure from a rainfall-induced (a) and irrigation-induced (b) runoff event. The 3.73-cm rainfall/runoff event shown in (a) ccurred on 17 Aug. 2010, and the irrigation/runoff event occurred on 3 Aug. 2010. translated into a RT that was more than two times less than irrigation events (Table 1). Regarding the impact of flow rate and RT on P removal by the structure, P removal on an event basis was negatively correlated to the weighted average event flow rate (Fig. 3). Similarly, in a previous study (McDowell et al., 2008) involving slag placed in subsurface drainage pipes, it was noted that larger events resulted in less contact time with the slag and lesser differences in dissolved $\mathrm{P}$ concentrations relative to control drains.

Although the weighted average RT for all rainfall runoff events was $18.9 \mathrm{~min}$, the RT for the six largest rainfall events that delivered $75 \%$ of the P to the P removal structure was only $8.9 \mathrm{~min}$. In addition, $54 \%$ of all the $\mathrm{P}$ removed by the structure (14.1 $\left.\mathrm{mg} \mathrm{kg}^{-1}\right)$ occurred over these six largest rainfall events.

\section{Predicting Lifetime and Performance of the Structure}

A predicted P removal curve estimated by the equations developed in Penn and McGrath (2011) for the electric arc furnace steel slag is shown in Fig. 4. This curve (Eq. [7]) describes the effect of P loading to the PSM on discrete P removal. This curve was produced by estimating its $\mathrm{Y}$ intercept (b) and its slope coefficient (m) with Eq. [8] and [9] in which RT and P inflow concentration are used as inputs. For the RT of the runoff in the P removal structure, we used 8.9 min (i.e., the RT for the 


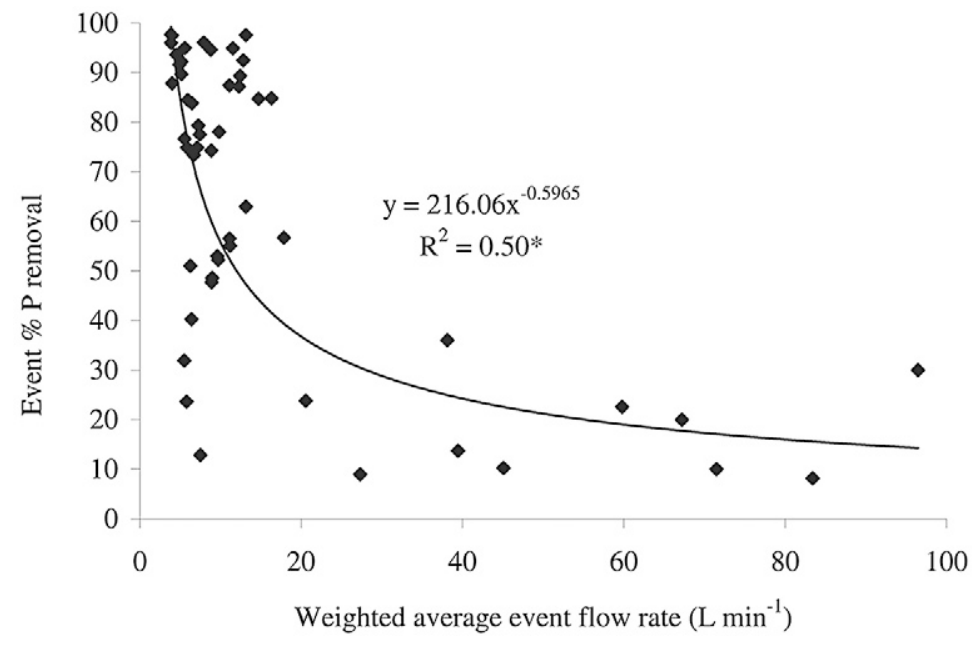

Fig. 3. Phosphorus (P) removal efficiency presented per event as impacted by the flow rate of runoff water passing through the ditch $P$ removal structure. *Significant at the 0.05 probability level.

six largest rainfall events that delivered $75 \%$ of the $\mathrm{P}$ to the $\mathrm{P}$ removal structure), whereas the average flow-weighted $\mathrm{P}$ inflow concentration was set at $0.74 \mathrm{mg} \mathrm{L}^{-1}$. The predicted P removal curve can be used to estimate the potential "lifetime" of the $\mathrm{P}$ removal structure. When discrete P removal approaches nearly zero (i.e., $1 \%$ ), then the slag is effectively "spent" and needs to be replaced with fresh PSM because the P inflow concentration will nearly equal the outflow concentration. The structure "lifetime" can be predicted using an estimate of P loading to the structure per unit time and the predicted maximum $P$ loading to the P removal structure at the point in which the PSM is "spent" (Eq. [11]). Using predicted values of the Y intercept (b) and the slope coefficient (m) from the flow-through equations (see above), a maximum cumulative loading of the $P$ removal structure amounting to $345 \mathrm{mg} \mathrm{kg}^{-1}$ was calculated using Eq. [11]. Based on the current $\mathrm{P}$ loading rate of the $\mathrm{P}$ removal structure (i.e., $20.5 \mathrm{mg} \mathrm{kg}^{-1} \mathrm{mo}^{-1}$ ), this would correspond to a potential lifetime of 16.8 mo. The measured $\mathrm{P}$

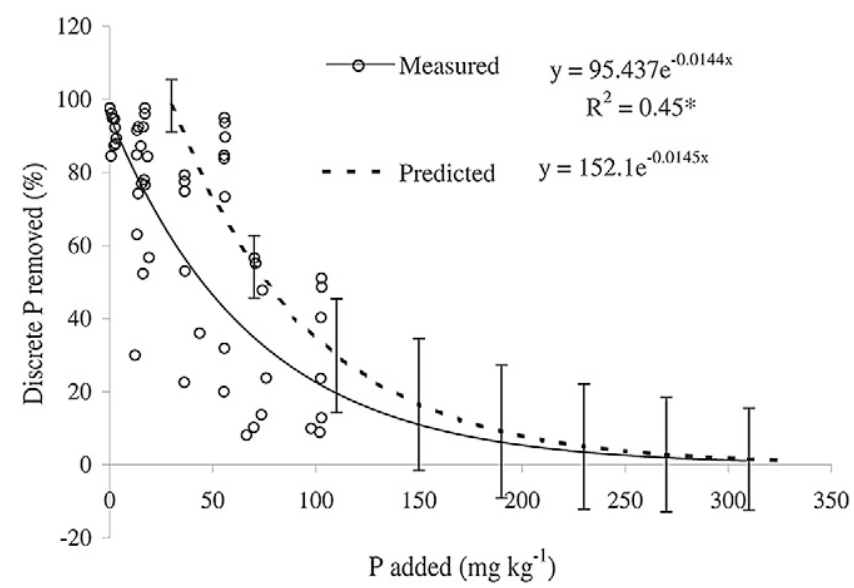

Fig. 4. Discrete phosphorus $(P)$ removal as a function of cumulative $P$ added to the ditch runoff $P$ removal structure. Predicted $P$ removal (dashed line) estimated based on average retention time and $\mathrm{P}$ concentration of the six largest rainfall events that delivered $75 \%$ of runoff $P$ load (average weighted retention time, $8.9 \mathrm{~min}$; total dissolved $P$ concentration, $0.74 \mathrm{mg} \mathrm{L}^{-1}$ ) using Eq. [7-10]. Measured discrete $P$ removal (open circles and solid line) calculated on a perevent basis. Error bars indicate a $95 \%$ confidence interval for the predicted $\mathrm{P}$ removal curve. * Significant at the $\mathbf{0 . 0 5}$ probability level. removal curve that was fitted to the field data of the actual discrete $\mathrm{P}$ removal and $\mathrm{P}$ loading of the $\mathrm{P}$ removal structure is shown in Fig. 4. Using the fitted values of the $\mathrm{Y}$ intercept (b) and the slope coefficient $(\mathrm{m})$, a maximum cumulative loading of $316 \mathrm{mg} \mathrm{kg}^{-1}$ was estimated with Eq. [11], which corresponds to a structure lifetime of $15.4 \mathrm{mo}$. Thus, the lifetime prediction of $16.8 \mathrm{mo}$ differs by a factor of only 1.09 of the projected lifetime using current structure performance data. In practice, one may be inclined to remove the slag material before $P$ saturation if environmental thresholds such as total maximum daily loads are exceeded. This estimate of filter lifetime does not take into account processes of sorbed $\mathrm{P}$ on the slag changing forms and allowing for more $\mathrm{P}$ sorption sites to become available, as described in Drizo et al. (2008). Apparently, such a factor did not have a significant impact on predicting filter lifetime due to near agreement (16.8 vs. 15.4 mo). However, a slow P sorption mechanism as described by Drizo et al. (2008) that was active would result in an underestimation of filter lifetime by the predicted P removal curve. The steel slag used in this study differed from that of Drizo et al. (2008) in that it was sieved to exclude fine particles.

The predicted P removal curve shown in Fig. 4 can be integrated to estimate the cumulative amount of $\mathrm{P}$ that the structure will remove as a function of $\mathrm{P}$ added (Eq. [10]). Figure 5 shows the predicted cumulative amount of $\mathrm{P}$ removed by the $\mathrm{P}$ removal structure as a function of $\mathrm{P}$ loading. For comparison, the measured values of the cumulative amount of $\mathrm{P}$ removed from runoff as a function of $\mathrm{P}$ loading of the $\mathrm{P}$ removal structure are shown. The predicted cumulative $P$ removal compared with the measured values showed that the flow-through equations used to produce the predicted $\mathrm{P}$ removal curve overestimated $\mathrm{P}$ removal. For example, after $5 \mathrm{mo}$ and a total $\mathrm{P}$ input of 103 $\mathrm{mg} \mathrm{kg}^{-1}$ to the $\mathrm{P}$ removal structure, the integrated predicted $\mathrm{P}$ removal curve estimated $79 \mathrm{mg} \mathrm{kg}^{-1}$ of $\mathrm{P}$ sorption, whereas the actual measured $\mathrm{P}$ sorption was $25.9 \mathrm{mg} \mathrm{kg}^{-1}$ (Table 1).

At the point of P saturation when the PSM is "spent," the integrated predicted $\mathrm{P}$ removal curve estimated a cumulative removal of $101 \mathrm{mg} \mathrm{P} \mathrm{kg}^{-1}$, or $28 \%$ of the total $\mathrm{P}$ added to the structure. This estimated value was obtained from the predicted P removal curve (Fig. 4), which was produced using Eq. [7-11] with an input of 8.9 min RT and $0.74 \mathrm{mg} \mathrm{L}^{-1}$ inflow (i.e., the conditions of the six largest rainfall events that delivered $75 \%$ of the P). Specifically, flow-through Eq. [8] and [9] predicted the $\mathrm{P}$ removal curve parameters $(\mathrm{b}$ and $\mathrm{m}$ ) for Eq. [7]; the resulting predicted design curve (Fig. 4) was integrated (Eq. [10]) (Fig. 5), which produced an estimate of maximum P removal under the conditions of the design curve (i.e., inflow $\mathrm{P}$ concentration and RT).

Apparently, the empirical flow-through equations were able to predict that $\mathrm{P}$ would be removed from runoff by the $\mathrm{P}$ removal structure as the $\mathrm{P}$ loading increased, but not to the correct degree in which it was occurring. This is likely due to the fact that the equations were unable to accurately predict the $\mathrm{Y}$ intercept (b) of the design curve (via Eq. [9]) (Fig. 4). The maximum amount of $\mathrm{P}$ projected to be removed by the structure (i.e., $0.065 \mathrm{~g} \mathrm{~kg}^{-1}$ determined from integration of the curve fitted to measured field data in Fig. 4) is low 
compared with other studies that have investigated the use of electric arc furnace steel slag for P sorption (Drizo et al., 2006; Drizo et al., 2002). For example, Drizo et al. (2002) achieved 1.35 to $2.35 \mathrm{~g} \mathrm{P}$ removed $\mathrm{kg}^{-1}$; however, their study used a much higher RT $(-8 \mathrm{~h})$ compared with the RT of the runoff in the $\mathrm{P}$ removal structure in our study. In addition, the large particle size fraction used in our study (i.e., 6.35-11 $\mathrm{mm}$ ) compared with previous studies (Kostura et al., 2005; Drizo et al., 2002) is not nearly as sorptive compared with the finer slag fraction (Stoner et al., 2012). However, the benefit of the large size fraction is higher hydraulic conductivity of the structure, which reduces the "footprint" or area of the $\mathrm{P}$ removal structure and allows more water to be treated compared with a finer-sized fraction.

Equations [8] and [9], which were used to estimate the $Y$ intercept (b) and the slope coefficient $(\mathrm{m})$ of the predicted design curve in Fig. 4, were developed using slag with the same size fraction collected from the same steel mill as slag used in the P removal structure but was collected at a different time (about 8 mo apart). In other words, cumulative P removal predictions from equations developed by Penn and McGrath (2011) are specific to their particular slag material, and any variation in slag properties would likely result in deviation from the predictions. This could explain why integration of the predicted $\mathrm{P}$ removal curve with sample-specific parameters indicated in Eq. [8] and [9] from Penn and McGrath (2011) overpredicted cumulative $\mathrm{P}$ removal as compared with measured values (Fig. 5). For example, the slag placed in the $\mathrm{P}$ removal structure contained less alkalinity and less total $\mathrm{Ca}$ and $\mathrm{Fe}$, and had a lower $\mathrm{pH}$ compared with the slag used to develop the flow through equations of Penn and McGrath (2011). Slag $\mathrm{pH}$ and alkalinity are integral to Ca phosphate precipitation (Bowden et al., 2009; Kostura et al., 2005). The role of Ca and $\mathrm{Fe}$ in $\mathrm{P}$ sorption by industrial by-products has been well documented (Penn et al., 2011; Leader et al., 2008). Lesser amounts of $\mathrm{Ca}$ and $\mathrm{Fe}$ would result in less $\mathrm{Ca}$ phosphate precipitation and $\mathrm{P}$ binding by $\mathrm{Fe}$ oxy/hydroxide minerals. The Langmuir $\mathrm{K}$ value was also much less for the slag sample used in this study compared with that used for development of flowthrough equations (i.e., 0.00126 vs. $2.43 \mathrm{~L} \mathrm{mg}^{-1}$, respectively, from Penn and McGrath, 2011).

\section{Other Water Quality Parameters}

Average $\mathrm{pH}$ of inflow and outflow treated water was 7.7 and 9.2 (SE, 0.04 and 0.08 , respectively). The increase in $\mathrm{pH}$ of the treated water was expected due to the elevated $\mathrm{pH}$ of the PSM tested in the laboratory (i.e., 9.4) (Table 2). However, alkalinity of the treated water was similar to inflow water; average inflow and outflow alkalinity was 77 and $81 \mathrm{mg} \mathrm{CaCO}_{3} \mathrm{~L}^{-1}$ (SE, 21 and

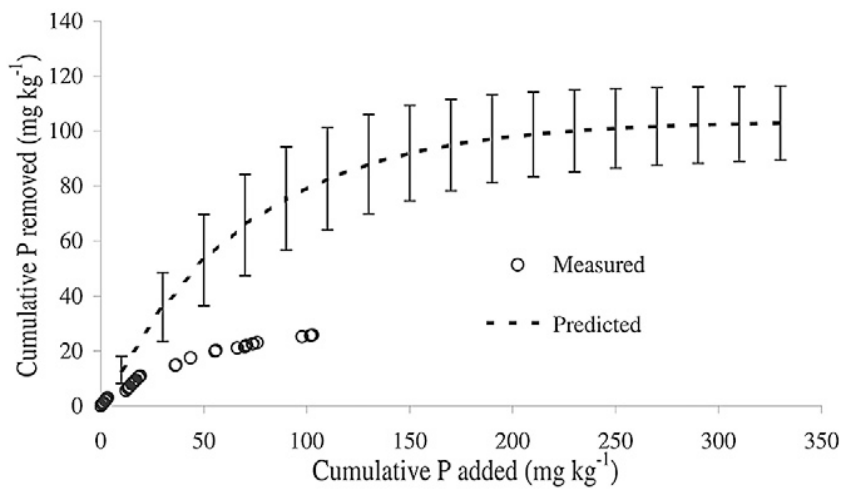

Fig. 5. Cumulative phosphorus $(P)$ removal by the ditch $P$ removal structure over a 5 -mo period as measured and predicted (dashed line) using a series of flow-through based equations (Eq. [7-10]). Predicted $\mathrm{P}$ removed estimated by integration of the curve presented in Fig. 4 using Eq. [10]. Error bars indicate 95\% confidence interval for the predicted $P$ removal based on the standard error for each model coefficient.

23 , respectively). A minimum alkalinity of $20 \mathrm{mg} \mathrm{L}^{-1}$ is required for ecosystems, and an alkalinity up to $400 \mathrm{mg} \mathrm{L}^{-1}$ has no impact on human health (USEPA, 1986).

For all inflow and treated water, $\mathrm{Zn}, \mathrm{Cu}, \mathrm{Cr}$, and $\mathrm{Mn}$ concentrations were all below detection limits (i.e., $0.01 \mathrm{mg} \mathrm{L}^{-1}$ ). Average $\mathrm{B}$ concentrations were similar among inflow and outflow treated waters (i.e., 0.14 and $0.15 \mathrm{mg} \mathrm{L}^{-1}$; SE, 0.003 and 0.005 , respectively). However, these $\mathrm{B}$ concentrations are not considered hazardous to aquatic life or B-sensitive agricultural crops (USEPA, 1986).

\section{Conclusions}

During the first 5 mo of operation, the P removal structure trapped $25 \%$ of runoff dissolved P. This could be improved by using the smaller particle size fraction of the slag, which is much more sorptive than the large fraction used in this study (Stoner et al., 2012). However, the smaller-sized fraction would reduce the hydraulic conductivity, thereby reducing the amount of water that can be treated during a large runoff event. Alternatively, the filter dimensions could be adjusted to allow for a higher RT. The flow-through equations presented in Penn and McGrath (2011) predicted a lifetime of 16.8 mo, which is similar to the projected lifetime of 15.4 mo based on current measurements. However, the flow-through equations overestimated current $\mathrm{P}$ removal (79 vs. $26 \mathrm{mg} \mathrm{P} \mathrm{kg}^{-1}$ ) by the $\mathrm{P}$ removal structure. Differences in $\mathrm{P}$ removal between predictions and measurements were likely a result of variability in slag chemical properties among slag used in the P removal structure and for development of flow-through equations. This emphasizes the need to develop a "universal" flow-through

Table 2. Chemical properties of the steel slag used in the suburban phosphorus removal structure.

\begin{tabular}{|c|c|c|c|c|c|c|c|c|c|c|c|c|c|}
\hline \multirow{2}{*}{$S_{\max }{ }^{\dagger}$} & \multirow{2}{*}{ K } & \multirow{2}{*}{$\mathrm{pH}$} & \multirow{2}{*}{ Alkalinity } & \multicolumn{5}{|c|}{ Total\# } & \multicolumn{5}{|c|}{ Water soluble } \\
\hline & & & & $\mathrm{Ca}$ & $\mathrm{Mg}$ & $\mathrm{S}$ & $\mathrm{Fe}$ & $\mathrm{Al}$ & $\mathrm{Ca}$ & $\mathrm{Mg}$ & $\mathrm{S}$ & $\mathrm{Fe}$ & $\mathrm{Al}$ \\
\hline $\mathrm{mg} \mathrm{kg}^{-1}$ & $\mathrm{~L} \mathrm{mg}^{-1}$ & & $\mathrm{mg} \mathrm{CaCO}_{3} \mathrm{~kg}^{-1}$ & & 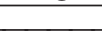 & 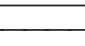 & 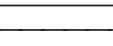 & $\mathrm{mg} \mathrm{kg}$ & 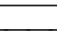 & & & & - \\
\hline $\begin{array}{l}11,658 \\
(5,604) \S\end{array}$ & $\begin{array}{l}0.00126 \\
(0.0001)\end{array}$ & $\begin{array}{c}9.4 \\
(0.15)\end{array}$ & $\begin{array}{l}558 \\
(63)\end{array}$ & $\begin{array}{c}195,331 \\
(9,186)\end{array}$ & $\begin{array}{l}54,221 \\
(2,270)\end{array}$ & $\begin{array}{c}4660 \\
(72)\end{array}$ & $\begin{array}{l}163,803 \\
(23,839)\end{array}$ & $\begin{array}{l}19,792 \\
(1,534)\end{array}$ & $\begin{array}{l}247 \\
(30)\end{array}$ & $\begin{array}{c}1.9 \\
(0.5)\end{array}$ & $\begin{array}{l}77 \\
(9)\end{array}$ & $\begin{array}{c}0 \\
(0)\end{array}$ & $\begin{array}{l}2.3 \\
(1)\end{array}$ \\
\hline
\end{tabular}

$+S_{\max }$ is the maximum sorption capacity of the soil. Langmuir isotherm $S_{\max }$ and $K$ values were estimated using Eq. [1].

\# Determined by EPA3051 digestion method.

$\S$ Values in parentheses indicate standard error. 
model that takes into account chemical characterization of sorption materials in addition to RT and $\mathrm{P}$ concentrations. Because $75 \%$ of all $\mathrm{P}$ delivered to the structure occurred over the six largest rainfall events, $P$ removal structures should be designed for handling these events to maximize P removal.

Compared with other best management practices, poultry litter transport programs and limitation of fertilizer P applications only prevent soil $\mathrm{P}$ from increasing further. This technology can help to prevent $\mathrm{P}$ losses to surface waters in the short term. In addition, the structure provides an easily quantified $\mathrm{P}$ removal that not only can be removed from the watershed but also may be useful to nutrient trading programs that are analogous to current carbon credit exchange programs (USEPA, 2001). Such programs apply a monetary value to $P$ discharged or transported from a site or prevented from being transported.

\section{Acknowledgments}

The authors thank the associate editor for his considerable time and effort invested in improving this manuscript.

\section{References}

Agrawal, S.G., K.G. King, J.F. Moore, P. Levinson, and J. McDonald. 2011. Use of industrial byproducts to filter phosphorus and pesticides in golf green drainage water. J. Environ. Qual. 40:1273-1280.

Baumann, T., S. Muller, and R. Niessner. 2002. Migration of dissolved heavy metal compounds and PCP in the presence of colloids through a heterogeneous calcareous gravel and a homogeneous quartz sand: Pilot scale experiments. Water Research 36:1213-1223.

Bolster, C.H., and G.M. Hornberger. 2007. On the use of linearized Langmuir equations. Soil Sci. Soc. Am. J. 71:1796-1806. doi:10.2136/ sssaj2006.0304

Bowden, L.I., A.P. Jarvis, P.L. Younger, and K.L. Johnson. 2009. Phosphorus removal from waste waters using basic oxygen steel slag. Environ. Sci. Technol. 43:2476-2481. doi:10.1021/es801626d

Cucarella, V., and G. Renman. 2009. Phosphorus sorption capacity of filter materials used for on-site wastewater treatment determined in batch experiments: A comparative study. J. Environ. Qual. 38:381-392. doi:10.2134/jeq2008.0192

Daly, K., P. Mills, B. Coulter, and M. McGarrigle. 2002. Modeling phosphorus concentrations in Irish rivers using land use, soil type, and soil phosphorus data. J. Environ. Qual. 31:590-599. doi:10.2134/jeq2002.0590

Drizo, A., J. Cummings, D. Weber, E. Twohig, G. Druschel, and B. Bourke. 2008. New evidence for rejuvenation of phosphorus retention capacity in EAF steel slag. Environ. Sci. Technol. 42:6191-6197. doi:10.1021/ es800232r

Drizo, A., C. Forget, R.P. Chapuis, and Y. Comeau. 2006. Phosphorus removal by electric arc furnace steel slag and serpentininte. Water Res. 40:15471554. doi:10.1016/j.watres.2006.02.001

Drizo, A., Y. Comeau, C. Forget, and R.P. Chapuis. 2002. Phosphorus saturation potential: A parameter for estimating the longevity of constructed wetland systems. Environ. Sci. Technol. 36:4642-4648. doi:10.1021/ es011502v

Gallimore, L.E., N.T. Basta, D.E. Storm, M.E. Payton, R.H. Huhnke, and M.D. Smolen. 1999. Water treatment residual to reduce nutrients in surface runoff from agricultural land. J. Environ. Qual. 28:1474-1478. doi:10.2134/jeq1999.00472425002800050012x

Harmel, R.D., H.A. Torbert, B.E. Haggard, R. Haney, and M. Dozier. 2004. Water quality impacts of converting to a poultry litter fertilization strategy. J. Environ. Qual. 33:2229-2242. doi:10.2134/jeq2004.2229

King, K.W., J.C. Balogh, K.L. Hughes, and R.D. Harmel. 2007. Nutrient load generated by storm event runoff from a golf course watershed. J. Environ. Qual. 36:1021-1030. doi:10.2134/jeq2006.0387

Koiv, M., M. Liira, U. Mander, R. Motlep, C. Vohla, and K. Kirsimae. 2010. Phosphorus removal using Ca-rich hydrated oil shale ash as filter material: The effect of different phosphorus loadings and wastewater com- positions. Water Res. 44:5232-5239. doi:10.1016/j.watres.2010.06.044

Kostura, B., H. Kulveitova, and J. Lesko. 2005. Blast furnace slags as sorbents of phosphate from water solutions. Water Res. 39:1795-1802. doi:10.1016/j.watres.2005.03.010

Leader, J.W., E.J. Dunne, and K.R. Reddy. 2008. Phosphorus sorbing materials: Sorption dynamics and physicochemical characteristics. J. Environ. Qual. 37:174-181. doi:10.2134/jeq2007.0148

Lee, J., R. Horton, and D.B. Jaynes. 2002. The feasibility of shallow time domain reflectometry probes to describe solute transport through undisturbed soil cores. Soil Sci. Soc. Am. J. 66:53-57. doi:10.2136/ sssaj2002.0053

Makris, K.C., and W.G. Harris. 2006. Time dependency and irreversibility of water desorption by drinking-water treatment residuals: Implications for sorption mechanisms. J. Colloid Interface Sci. 294:151-154. doi:10.1016/j.jcis.2005.06.091

McDowell, R.W., A.N. Sharpley, and W. Bourke. 2008. Treatment of drainage water with industrial by-products to prevent phosphorus loss from tile-drained land. J. Environ. Qual. 37:1575-1582. doi:10.2134/ jeq2007.0454

Penn, C.J., and R. Bryant. 2006. Application of phosphorus sorbing materials to streamside cattle loafing areas. J. Soil Water Conserv. 61:303-310.

Penn, C.J., R.B. Bryant, M.A. Callahan, and J.M. McGrath. 2011. Use of industrial byproducts to sorb and retain phosphorus. Commun. Soil Sci. Plant Anal. 42:633-644. doi:10.1080/00103624.2011.550374

Penn, C.J., R.B. Bryant, P.A. Kleinman, and A. Allen. 2007. Sequestering dissolved phosphorus from ditch drainage water. J. Soil Water Conserv. 62:269-272.

Penn, C.J., and J.M. McGrath. 2011. Predicting phosphorus sorption onto steel slag using a flow-through approach with application to a pilot scale system. J. Water Resour. Prot. 3:235-244. doi:10.4236/jwarp.2011.34030

Penn, C.J., J.M. McGrath, and R.B. Bryant. 2010. Ditch drainage management for water quality improvement. p. 151-173. In M.T. Moore (ed.) Agricultural drainage ditches: Mitigation wetlands for the 21st century. Research Signpost, Kerala, India.

Pionke, H.B., W.J. Gburek, R.R. Schnabel, A.N. Sharpley, and G.F. Elwinger. 1999. Seasonal flow, nutrient concentrations and loading patterns in stream flow draining an agricultural hill-land watershed. J. Hydrol. 220:62-73. doi:10.1016/S0022-1694(99)00064-5

Pionke, H.B., W.J. Gburek, A.N. Sharpley, and J.A. Zollweg. 1997. Hydrologic and chemical controls on P loss from catchments. p. 225-242. In H. Tunney, O.T. Carton, P.C. Brookes, and A.E. Johnston (ed.) Phosphorus loss from soil to water. CAB International Publishers, New York.

Rhoton, F.E., and J.M. Bigham. 2005. Phosphate adsorption by ferrihydriteamended soils. Soil Sci. Soc. Am. J. 34:890-896.

Sharpley, A.N., P.J.A. Kleinman, A.L. Heathwaite, W.J. Gburek, J.L. Weld, and G.J. Folmar. 2008. Integrating contributing areas and indexing phosphorus loss from agricultural watersheds. J. Environ. Qual. 37:1488-1496. doi:10.2134/jeq2007.0381

Stoner, D., C.J. Penn, J.M. McGrath, and J.G. Warren. 2012. Phosphorus removal with by-products in a flow-through setting. J. Environ. Qual. 41:654-663. doi:10.2134/jeq2011.0049

Toride, N., F.J. Leij, and M.Th. van Genuchten. 1999. The CXTFIT code for estimating transport parameters from laboratory or field tracer experiments, version 2.1. Research Rep. 137. USDA-ARS, U.S. Salinity Laboratory, Riverside, CA.

Udawatta, R.P., P.P. Motavalli, and H.E. Garrett. 2004. Phosphorus loss and runoff characteristics in three adjacent agricultural watersheds with claypan soils. J. Environ. Qual. 33:1709-1719. doi:10.2134/jeq2004.1709

USEPA. 1986. Quality criteria for water. EPA Rep. 440/5-86-001. USEPA, Office of Water Regulations and Standards, Washington, DC.

USEPA. 1997. Method 3051a: Micro-wave assisted acid dissolution of sediments, sludges, soils, and oils. 2nd ed. U.S. Gov. Print. Office, Washington, DC.

USEPA. 2001. Chesapeake Bay program nutrient trading fundamental principles and guidlines. EPA 903-B-01-001. CBP/TRS 254/01. USEPA Report Collection, Regional Center for Environmental Information, USEPA Region 3, Philadelphia, PA.

Wei, X., R.C. Viadero, Jr., and S. Bhojappa. 2008. Phosphorus removal by acid mine drainage sludge from secondary effluents of municipal wastewater treatment plants. Water Res. 42:3275-3284. doi:10.1016/j. watres.2008.04.005 